Valentyna Todorova,

doctoral candidate, Lviv State University of Physical Culture,

11, Kostiushka Str., Lviv, Ukraine

\title{
PECULIARITIES OF OBJECTIVE EVALUATION OF CHOREOGRAPHIC PREPAREDNESS AT DIFFERENT STAGES OF LONG-TERM ATHLETIC PERFORMANCE (THROUGH THE EXAMPLE OF AEROBIC GYMNASTICS)
}

The paper demonstrates the opportunities of objective evaluation of choreographic preparedness of athletes majoring in aerobic gymnastics. There has been proposed the scale of evaluating aesthetic and technical components according to the following criteria: body alignment, turnout, stretched knees and pointed toes, stability, precision and completeness of movements, airiness and fluency of movements, musicality, dancing style, illustrative and emotional expression. The levels of these criteria development has been described; and the levels of gymnasts' choreographic preparedness at different stages of athletic performance have been distinguished.

Keywords: choreographic training, evaluation, criteria, level of choreographic preparedness, athletes, programme choreography.

Introduction. In sports with complex coordination (for example, in artistic and rhythmic gymnastics, figure skating, acrobatic rock-n-roll, diving, synchronised swimming, trampolining, aerobic gymnastics), competition exercises are the principal component of a contest $[1 ; 6 ; 7 ; 10]$. Competition exercises in these kinds of sports are various combinations performed under standard conditions that are different in conformity of movement plastique, dancing style, compliance with aesthetic principles, which makes objective evaluation difficult. For characterising the choreography of competition exercises, some subjective, imprecise qualitative criteria are used $[4 ; 14]$. Due to the lack of any quantity indexes, there appear certain difficulties in terms of judging objectivity and in the process of training.

In scientific, methodical and specialist literature, there are some findings about motor actions that are characterised by expressiveness, aesthetic qualities, and artistry of competition compositions in sports with complex coordination. However, the opportunities of objective evaluation of choreographic preparedness in aerobic gymnastics as a relatively new kind of sports with complex coordination are understudied and should be investigated further.

The issues of judging objectivity in sports with strict requirements to choreographic preparedness have been studied by a great number of authors. The researchers attempt to reduce judging subjectivity and improve the requirements to evaluation of the quality of performing "programme choreography" by means of quantitative methods. The key points of these methods involve experts' evaluation of emotional meanings of motor actions by means of correlating the concepts with certain adjectives (for example, temperamental, audacious, enthusiastic, amusing, sentimental, etc.) and quantitative estimation of the degree of each feature's manifestation $[3 ; 4 ; 6 ; 8 ; 12$ and others].

By using various methods of choreography evaluation, the requirements to athletes' choreographic preparedness have been characterised for artistic and rhythmic gymnastics $[3 ; 4 ; 6 ; 8 ; 13]$, acrobatic rock-n-roll [5;9], figure skating [11] and other kinds of sports with complex coordination. As for aerobic gymnastics, this issue remains underinvestigated. In our opinion, this problem can be solved with the help of objective evaluation of choreographic preparedness that is based on the data presented in specialist literature, methodology of forming motor skills in classical choreography developed by A. Vahanova [2] and the requirements of classical dance.

The paper is aimed at describing the ways of objectification of evaluating choreographic preparedness of athletes majoring in aerobic gymnastics.

The tasks of the paper are the following:

1) to review special literature with the purpose of specifying criteria of choreographic preparedness evaluation;

2) to create the scale of quantitative and qualitative evaluation of choreographic preparedness in aerobic gymnastics;

3) to test the proposed scale of evaluating choreographic preparedness in female gymnasts' training;

4) to identify the levels of choreographic preparedness at different levels of long-term athletic performance.

Research methods. We have examined 181 female gymnasts belonging to different age groups from Odesa and Odesa region including 59 girls aged 6-10 years at the stage of initiative training; 61 girls aged 11-14 years at the stage of preliminary basic training; 61 female gymnasts aged 15-17 years at the stage of specialised basic training. All the participants agreed to take part in the experiment. The research was carried out at the premises of the Federation of Aerobic Gymnastics, Comprehensive Schools No. 81 and 111, Specialised Children and Youth Sports School of the Olympic Reserve No. 10, Youth Sports School No. 1, and Complex Youth Sports School No. 3 (Odesa).

In order to specify the theoretical bases of the study, we used comparative method, systematisation of scientific literature on the studied issue. Also, we tested choreographic preparedness of female gymnasts and identified 
the level of development of the main components of choreographic preparedness (technical and aesthetic).

In the course of statistical processing of the findings, the following statistical characteristics were calculated: arithmetic mean $(\mathrm{M})$, standard deviation $( \pm \mathrm{SD})$, concordance coefficient. Besides, we have calculated the individual coefficient of criterion formation $(k)$ that indicated correlation between the sum of experts' scores and their quantity for each specific criterion. It was calculated as follows:

$$
k=\frac{\sum \mathrm{O}}{N}
$$

where $k$ is the individual coefficient of criterion formation; $\Sigma$ - the sum; $O-$ the score; $N$ - the number of experts.

Individual index of athletes' choreographic preparedness $(I)$ was calculated as the arithmetic mean of individual coefficients of formation $(k)$ according to all thirteen criteria. In order to characterise the group's level of particular criteria formation, the group coefficient of formation level was calculated $\left(k_{g r}\right)$ as the arithmetic mean $k$. The group index of athletes' choreographic preparedness $\left(I_{g r}\right)$ was calculated as the arithmetic mean $k_{g r}$.

Discussion. Having carried out the research, we obtained some data that made it possible to estimate the level of gymnasts' choreographic preparedness.

The review of specialist literature allowed us to define choreographic preparedness in aerobic gymnastics as a complex system of motor qualities and capabilities, which consists of two components (technical and aesthetic) and is expressed by perfect body alignment; good turnout; stretched knees and pointed toes; stability; proper coordination of leg and arm movements; completeness, airiness and fluency of movements; demonstrations of musicality, dancing style, illustrative and emotional expression. Thus, the criteria of choreographic preparedness are choreography elements that can be evaluated qualitatively and quantitatively, which makes it possible to avoid subjectivism.

"Technical" criteria include body alignment; turnout, stretched knees and pointed toes; stability; precision of leg and arm movements; completeness, airiness and fluency of movements. The "aesthetic" ones include musicality, dancing style, illustrative and emotional expression.

The choice of these particular criteria for evaluating this kind of preparedness is conditioned by the peculiarities of "choreographic elements" technique in complex coordination sports, which involves correspondence of the shape and character of movements to the established traditions of choreography and gymnastics, biomechanical relevance, standards of the style of a certain kind of sports.

For more precise and differentiated evaluation, we have proposed five-point scale, according to which 0.5 points were given if the criterion was formed very poorly; 1 point if the criterion is insufficient for successful mastering of choreographic training programme; 1.5 points - if the criteria is formed sufficiently for the successful mastering of choreographic training programme; 2 points - if the criterion is formed well; and 2.5 - if the criterion is formed perfectly.
A group of experts representing five kinds of sports (choreographers and aerobic gymnastics coaches) was engaged in testing the scale. The experts were offered a number of criteria for evaluating choreographic preparedness with their detailed description. All the criteria were evaluated according to the requirements for the technique of performing choreographic elements in terms of choreography and contest rules. The efficiency of the proposed evaluation technique was proven by concordance method. As long as concordance coefficient is $>0.7$, it is fair to say that the data obtained after experimental testing are concerted.

To simplify delivering and interpretation of facts, the borders of low, sufficient and high level of athletes' choreographic preparedness have been identified. For this purpose, arithmetic mean $(\mathrm{M}=1.52)$ and standard deviation $(\mathrm{SD}=0.21)$ of individual indexes of choreographic preparedness of all the study participants have been calculated; and the intervals between scores taken as a basis of the author's scheme of results interpretation have been identified: the low level (less than 1.2 points) - prevalence of serious errors in performing most choreographic elements; the sufficient level $(1.3-1.7)$ is characterised by miscues in performing some details of the technique, which reduces effect of the performance in general; the optimum level (more than 1.8 points) - perfectly correct performance of most choreographic elements.

Therefore, the low level is characterised by considerable deviations of certain criteria from the ones that are stated in contest rules and limited by choreographic requirements: "body alignment"- deviation from vertical plane within the limits of $10^{\circ}$ and more (body broad axis is $<180^{\circ}$, the angle between body broad axis and neck as well as between jawline and neck is $\left\langle 90^{\circ}\right.$ ); "turnout"- the angle of turning hips, knees, feet outwards is $<90^{\circ}$; "stretched knees and pointed toes"- knee extension angle is $<180^{\circ}$, ankle angle is $<180^{\circ}$; "stability"- lack of balance (body swinging); "precision of leg movements"in grand plié and demi plié pelvis is brought out behind the heel line by $<90^{\circ}$, in battement working leg is not in line with the heel of supporting leg, leg split angle is $<180$, scissors leap, split angle is $<150^{\circ}$, split jump (side split) is $<170^{\circ}$; "precision of arm movements"- elbowshoulder-hand do not form one line, fingers are separated; "completeness of movements"- no accentuated hand motion when completing the movement; "airiness of movements"- observable efforts when performing the movements; "fluency of movements"- observable pauses when switching from one movement to another; "musicality"- movements do not correspond to music tempo and rhythm; "dancing style"- dance movements do not correspond to the genre of dance and background music; "illustrative expression" - lack of coordination between arms, head, body and leg movements that emphasise direction and character of the pose; "emotional expression" - no motions corresponding to observable demonstrations of emotions and feelings (facial expression) matching background music. 
The sufficient level: "body alignment"- slight deviation from vertical plane within the limits of $10^{\circ}$; "turnout"- the angle of turning hips, knees, feet outwards is $<90^{\circ}$; "stretched knees and pointed toes"- knee extension angle is $<180^{\circ}$, ankle angle is $<180^{\circ}$; "stability" - slight body swinging with keeping the balance; "precision of leg movements" - imprecise movements of supporting and working leg; "precision of arm movements" imprecision of arm position; "completeness of movements" - hand motion when completing the movement is not always accentuated; "airiness of movements" - small efforts when performing the movements; "fluency of movements" - some pauses when switching from one movement to another; "musicality" - movements do not always correspond to music tempo and rhythm; "dancing style" - dance movements do not always correspond to the genre of dance and background music; "illustrative expression" - insufficient coordination between arms, head, body and leg movements that emphasise direction and character of the pose; "emotional expression" - performing motions without corresponding demonstrations of emotions and feelings (facial expression) matching background music.

The optimum level: "body alignment" - vertical back, body broad axis in a frontal plane $-180^{\circ}$, the angle between body broad axis and neck as well as between jawline and neck is $90^{\circ}$; "turnout" - the angle formed by the longitudinal arch lines (right and left foot) when turning the hip ranges from $90^{\circ}$ to $180^{\circ}$; "stretched knees and pointed toes" - knee extension angle equals to $180^{\circ}$, ankle angle equals to $180^{\circ}$; "stability" - no swinging of the body, keeping the balance; "precision of leg movements"- in grand plié and demi plié pelvis is not brought out behind the heel line, the knees are bent sideways up to $90^{\circ}$, in battement working leg is in line with the heel of supporting leg, leg split angle is $>180^{\circ}$, scissors leap, split angle is $>150^{\circ}$, split jump (side split) is $>170^{\circ}$; "precision of arm movements" - elbow-shoulderhand form straight line (frontwards and sidewards this line is parallel to a horizontal plane), fingers are close to each other; "completeness of movements" - observable accentuated hand motion when completing the movement; "airiness of movements" - performing the movements without observable efforts; "fluency of movements" continuous movements; "musicality" - movements correspond to music tempo and rhythm; "dancing style" dance movements correspond to the genre of dance and background music; "illustrative expression" - coordination of arms, head, body and leg movements that emphasize direction and character of the pose; "emotional expression" - performing motions corresponding to observable demonstrations of emotions and feelings (facial expression) matching background music.

With the aim of determining the level of choreographic preparedness, the mean score of all the criteria $(k)$ was calculated for each athlete individually on the basis of the sum of five experts' scores.

Table 1 presents the data of individual levels of formation of choreographic preparedness criteria.

The level of formation of athletes' choreographic preparedness criteria

Table 1. at different stages of long-term athletic performance (\%)

\begin{tabular}{|l|c|c|c|c|c|c|c|c|c|}
\hline \multirow{2}{*}{ Criteria } & \multicolumn{3}{|c|}{ Initial training } & \multicolumn{3}{c}{ Preliminary basic training } & \multicolumn{3}{c|}{ Specialised basic training } \\
\cline { 2 - 12 } & I & II & III & I & II & III & I & II & III \\
\hline Body alignment & 0 & 13 & 87 & 10 & 27 & 63 & 28 & 20 & 52 \\
\hline Turnout & 13 & 17 & 70 & 15 & 22 & 65 & 30 & 20 & 50 \\
\hline $\begin{array}{l}\text { Stretched knees and pointed } \\
\text { toes }\end{array}$ & 12 & 20 & 68 & 32 & 10 & 58 & 27 & 18 & 55 \\
\hline Stability & 17 & 23 & 60 & 37 & 17 & 47 & 18 & 32 & 50 \\
\hline Precision of leg movements & 0 & 12 & 88 & 42 & 15 & 43 & 15 & 27 & 58 \\
\hline Precision of arm movements & 0 & 10 & 90 & 28 & 0 & 72 & 22 & 28 & 50 \\
\hline Completeness & 10 & 10 & 80 & 37 & 3 & 60 & 23 & 28 & 48 \\
\hline Airiness & 5 & 23 & 72 & 12 & 35 & 53 & 22 & 27 & 52 \\
\hline Fluency of movements & 8 & 13 & 78 & 8 & 33 & 58 & 27 & 27 & 47 \\
\hline Musicality & 15 & 25 & 60 & 33 & 32 & 35 & 13 & 28 & 58 \\
\hline Dancing style & 3 & 22 & 75 & 0 & 38 & 62 & 3 & 28 & 68 \\
\hline Illustrative expression & 2 & 50 & 48 & 0 & 10 & 90 & 0 & 27 & 73 \\
\hline Emotional expression & 18 & 72 & 10 & 0 & 10 & 90 & 0 & 25 & 75 \\
\hline
\end{tabular}

Note: I-optimum level, II - sufficient level; III - low level 
Analysis of the group level of certain criteria formation (which was calculated as a group coefficient of formation level $-k_{g r}$ ) has shown that at the stage of initial training the following criteria of choreographic preparedness were characterised by the low level of formation: body alignment $\left(k_{g r}=1.05 \pm 0.02\right)$; stretched knees and pointed toes, leg stability $\left(k_{g r}=1.2 \pm 0.05 ; 1.3 \pm 0.05\right)$; precision of leg and arm movements $\left(k_{g r}=1 \pm 0.02 ; 1 \pm 0.002\right)$; completeness, airiness and fluency of movements $\left(k_{g r}=1.2 \pm 0.4 ; 1.2 \pm 0.03 ; 1.1 \pm 0.03\right)$; musicality and dancing style $\left(k_{g r}=1.2 \pm 0.05 ; 1.2 \pm 0.03\right)$. Illustrative and emotional expression were formed at the sufficient level $-k_{g r}=1.3$ $1.5 \pm 0.02(\mathrm{p}<0.05)$. At the stage of initial training, the best indexes of choreographic preparedness were observed upon the criterion "emotional expression" (among the athletes under study, the optimum level was observed in 11 participants $(18 \%)$ ). It can be explained by the fact that children of this age have dominating right brain that is responsible for figural information processing and eyemindedness, which affects high emotionality of their behaviour, in this case - emotional expression. Older female athletes demonstrate a contradiction: the level of emotionality reduces with the increasing level of technical preparedness and complexity of contest programmes. In most cases, the gymnasts try to show technically correct performance, which reduces emotional expression.

At the stage of preliminary basic training, evaluation of group coefficient of certain criteria formation has shown that such indexes as body alignment, turnout, dancing style $\left(k_{g r}=1.2 \pm 0.03\right)$, illustrative and emotional expression $\left(k_{g r}=1.1 \pm 0.02\right)$ are at the low level $(\mathrm{p}<0.05)$. Other group indexes were developed at the sufficient level $-k_{g r}$ in the range of 1.3-1.5, though the results obtained cannot be considered as statistically significant ( $p>0.05$ ).

At the stage of specialised basic training, the level of formation of most criteria of choreographic preparedness can be considered as sufficient $\left(k_{g r}\right.$ in the range of 1.31.4); however, such criteria as dancing style, illustrative and emotional expression are at the low level $\left(k_{g r}\right.$ in the range of 1.1-1.2 $\pm 0.03 ; \mathrm{p}<0.05)$.

\section{REFERENCES}

1. Aerobnaya gimnastika: Proekt pravil sorevnovaniy 2013-2016 [Aerobic gymnastics: contest rules project] (2012). Retrieved from: http://www.figaerobic.com./2013-2016-AEROBIC-GYMNASTICSCOPE-OF-POINTS Russian-a977.html [in Russian].

2. Vaganova, A. Ya. (2000). Osnovy klassicheskogo tantsa: uchebnik dlya vuzov [Fundamentals of classical dance: textbook for universities]. St. Petersburg: Lan [in Russian].

3. Gaverdovskiy, Yu. K. (2012). Sovershenstvovanie tekhniki dvizheniya i spetsialnoy tekhnicheskoy podgotovki kak osnova vysshikh dostizheniy $\mathrm{v}$ sovremennoy sportivnoy gimnastike [Improvement of movement technique and special technical training as a basis for highest achievements in contemporary artistic gymnastics]. Sovremennaya sistema
The data obtained made it possible to identify that the group index $\left(I_{g r}\right)$ of choreographic preparedness formation at the stage of initial training corresponds to the low level $\left(I_{i t}=1.2\right)$.

At the stages of preliminary and specialised basic training, the level of choreographic preparedness is at the sufficient level $\left(I_{p b}=1.5 ; I_{s b}=1.6\right)$.

Conclusions and prospects for further research. Review of scientific literature and the author's own experience in teaching and training demonstrate the necessity for searching the ways for improving choreographic preparedness by means of developing objective evaluations of programme choreography at all the stages of long-term athletic performance.

The scale of evaluating gymnasts' choreographic preparedness was proposed; it included the evaluation of the following criteria: body alignment; turnout; stretched knees and pointed toes; stability; precision of leg and arm movements; completeness, airiness and fluency of movements; musicality; dancing style; illustrative and emotional expression.

The proposed methodology was tested by a group of five sports experts (choreographers and aerobic gymnastics coaches) in the course of choreographic training. Consistency of evaluation results was confirmed by concordance coefficient $(>0.7)$.

The levels of choreographic preparedness at different stages of long-term athletic performance were specified by calculating the index of certain criteria formation. It has been found that the group index of choreographic preparedness formation $\left(I_{g r}\right)$ at the stage of initial training is at the low level $\left(I_{i t}=1.2\right)$; at the stages of preliminary and specialised basic training, choreographic preparedness was formed at the sufficient level $\left(I_{p b}=1.5 ; I_{s b}=1.6\right)$. The optimum level of choreographic preparedness was not demonstrated at any of the stages. Therefore, it is reasonable to analyse the factors that set limits for the level of choreographic preparedness.

sportivnoy podgotovki gimnastov - Contemporary system of training gymnasts: Proceedings of International research and practice conference, 1, 7-27. Kyiv: Nauka v Olimpiyskom sporte [in Russian].

4. Kabayeva, A. M., \& Plekhanova, M. Ye. (2009). Esteticheskiy komponent sorevnovatelnykh programm gimnastov [Aesthetic component of gymnasts' competitive programmes]. Uchenye zapiski - Scholarly notes, 4(50), 54-57 [in Russian].

5. Kyzim, P. M., Lutsenko, L. S., \& Batieieva, N. P. (2016). Udoskonalennia zmahalnoi prohramy zhinochoi pary z akrobatyky zasobamy khoreohrafii na etapi spetsializovanoi bazovoi pidhotovky [Updating the contest programme of woman's pair in acrobatics by means of choreography at the stage of specialized basic training]. Slobozhanskyi naukovo-sportyvnyi visnyk - 
Slooda Ukrainian bulletin of science and sports, 2(52), 55-60. Kharkiv: KhDAFK. doi:10. 15391/snsv.2016-2009 [in Ukrainian].

6. Lisitskaya, T. S. (1985). Khoreografiya $v$ gimnastike [Choreography in gymnastics]. Moscow: Fizkultura i sport [in Russian].

7. Platonov, V. N. (2004). Sistema podgotovki sportsmenov $v$ olimpiyskom sporte. Obshchaya teoriya $i$ ee prakticheskie prilozheniya [The system of training athletes in the Olympic sports. General theory and its practical application]. Kyiv: Olimpiyskaya literatura [in Russian].

8. Sosina, V. Yu. (2009). Khoreografiya $v$ gimnastike: ucheb. posobie dlya studentov vuzov [Choreography in gymnastics: textbook for university students]. Kyiv: Olimpiyskaya literatura [in Russian].

9. Todorova, V. H. (2016). Analiz prohramnonormatyvnoho zabezpechennia $\mathrm{z}$ khoreohrafichnoi pidhotovky u skladnokoordynatsiinykh vydakh sportu [Analysis of programme and standards of choreographic training in complex coordination sports]. Fizychna aktyvnist, zdorovia i sport: naukovyi zhurnal - Physical activity, health and sport: academic journal, 1, 23-32. Lviv: Lvivskyi derzhavnyi universytet fizychnoi kultury [in Ukrainian].

10. Todorova, V. H. (2015). Suchasnyi stan i perspektyvy khoreohrafichnoi pidhotovky $\mathrm{v}$ skladnokoordynatsiinykh vydakh sportu [Current state

\section{ЛІТЕРАТУРА}

1. Аэробная гимнастика : Проект правил соревнований 2013-2016 [Электронный ресурс]. - Режим доступа : http://www.fig-aerobic.com./2013-2016AEROBIC-GYMNASTICS-COPE-OF-POINTSRussiana977.html.

2. Ваганова А. Я. Основы классического танца : учебник для вузов / А. Я. Ваганова. - СПб. : Лань, 2000. - 192 c.

3. Гавердовский Ю. К. Совершенствование техники движения и специальной технической подготовки как основа высших достижений в современной спортивной гимнастике / Ю. К. Гавердовский // Международная научно-практическая конференция «Современная система спортивной подготовки гимнастов». - К. : Наука в Олимпийском спорте, 2012. №1. - C. 7-27.

4. Кабаева А. М. Эстетический компонент соревновательных программ гимнастов / А. М. Кабаева, М. Э. Плеханова // Ученые записки. - 2009. - №4(50). - C. 54-57.

5. Кизім П. М. Удосконалення змагальної програми жіночої пари з акробатики засобами хореографії на етапі спеціалізованої базової підготовки / П. М. Кизім, Л. С. Луценко, Н. П. Батєєва // Слобожанський науково-спортивний вісник. - Харків : ХДАФК, 2016. - № 2(52). - C.55-60. - doi:10. 15391/snsv.2016-2009. and prospects for choreographic training in complex coordination sports]. Nauka i osvita: naukovo-praktychnyi zhurnal - Science and education: academic journal, 5, 119-124. Odesa [in Ukrainian].

11. Medvedieva, I. M. (1999). Fihurne katannia na kovzanakh. Navchalna prohrama dlia dytiachoyunatskykh sportyvnykh shkil, spetsializovanykh dytiachoyunatskykh shkil olimpiiskoho rezervu, shkil vyshchoi sportyvnoi maisternosti [Figure skating. Training programme for youth athletic centres, specialized children and youth sports school of the Olympic reserve and schools of higher sports skills]. O. P. Morhushenko (Ed.). Kyiv: Derzhkomsportu Ukrainy z fizychnoi kultury i sportu [in Ukrainian].

12. Shipilina, I. (2004). Khoreografiya $v$ sporte: uchebnik dlya studentov [Choreography in sports: text book for students]. Rostov-on-Don: Feniks [in Russian].

13. Bradshaw, E., Hume, P., Carlton, M., \& Aisbett, B. (2010). Reliability and variability of day-to-day vault training measures in artistic gymnastics. Sports Biomechanics, 9(2), 79-97. doi: 1080/14763141.2010.488298. [in English].

14. Gautier, G., Thouvarecq, R., \& Larue, J. (2008). Influence of Experience on Postural Control: Effect of Expertise in Gymnastics. Journal of Motor Behavior, 40(5), 400-408. doi:10.3200/ JMBR.40.5.400-408. [in English].

6. Лисицкая Т. С. Хореография в гимнастике / Т. С. Лисицкая. - М. : Физкультура и спорт, 1985. $176 \mathrm{c}$.

7. Платонов В. Н. Система подготовки спортсменов в олимпийском спорте. Общая теория и ее практические приложения / В. Н. Платонов. - К. : Олимпийская литература, 2004. - 808 с.

8. Сосина В. Ю. Хореография в гимнастике : учеб. пособие для студентов вузов / В. Ю. Сосина. К. : Олимпийская литература, 2009. - 135 с.

9. Тодорова В. Г. Аналіз програмнонормативного забезпечення з хореографічної підготовки у складнокоординаційних видах спорту / В. Г. Тодорова // Фізична активність, здоров'я і спорт : науковий журнал. - Львів : Львівський державний університет фізичної культури, 2016. - №1 - С. 23-32.

10. Тодорова В. Г. Сучасний стан і перспективи хореографічної підготовки в складнокоординаційних видах спорту / В. Г. Тодорова // Наука і освіта : науково-практичний журнал. - 2015. - №5. - С. 119-124.

11. Фігурне катання на ковзанах. Навчальна програма для дитячо-юнацьких спортивних шкіл, спеціалізованих дитячо-юнацьких шкіл олімпійського резерву, шкіл вищої спортивної майстерності / I. М. Медведєва; за ред. Моргушенко О. П. - Київ : Держкомспорту України з фізичної культури і спорту, 1999. - 105 c. 
12. Шипилина И. Хореография в спорте : учебник для студентов / И. Шипилина. - Ростов на Дону : Феникс, 2004. - 224 с.

13. Bradshaw E. Reliability and variability of dayto-day vault training measures in artistic gymnastics / E. Bradshaw, P. Hume, M. Carlton, B. Aisbett // Sports biomechanics. - 2010. - 9(2). - P. 79-97. - doi: 1080/14763141.2010.488298.

14. Gautier G. Influence of experience on postural control: Effect of expertise in gymnastics / G. Gautier, R. Thouvarecq, J. Larue // Journal of Motor Behavior. 2008. - 40(5). - P. 400-408. - doi:10.3200/ JMBR.40.5.400-408.

\section{Валентина Георсіӥвна Тодорова, докторант, Львівський державний університет фізичної культури, вул. Костюшка, 11, м. Львів, Украӥна}

\section{ОСОБЛИВОСТІ ОБ'ЄКТИВНОГО ОЦІНЮВАННЯ ХОРЕОГРАФІЧНОЇ ПІДГОТОВЛЕНОСТІ НА РІЗНИХ ЕТАПАХ БАГАТОРІЧНОЇ СПОРТИВНОЇ ПІДГОТОВКИ (НА ПРИКЛАДІ АЕРОБНОЇ ГІМНАСТИКИ)}

Актуальність дослідження обумовлена відсутністю кількісних показників хореографічної підготовленості в аеробній гімнастиці. У зв’язку з цим виникає проблема як в об'єктивності суддівства, так і в тренувальному процесі. Наше дослідження допоможе подолати протиріччя, які виникають між необхідністю об'єктивізації процесу хореографічної підготовки в складнокоординаційних видах спорту і недостатністю детально розробленої методики об'єктивної оцінки хореографічної підготовленості на різних етапах багаторічної підготовки. Метою статті була оцінка хореографічної підготовленості спортсменів, що спеціалізуються в аеробній гімнастиці. Методи дослідження: для визначення теоретичних позицій дослідження були застосовані методи порівняння, систематизації наукових джерел із досліджуваної проблеми. Для визначення рівня розвитку основних компонентів хореографічної підготовленості (технічного та естетичного) було проведено тестування хореографічної підготовленості гімнасток. Для встановлення адекватності методики об'єктивної оцінки хореографічної підготовленості гімнасток був застосований метод конкордації; для інтерпретації фактичної інформації використовувалися програми Excel for Windows i «Statistica 6.0». Запропоновано шкалу оцінки хореографічної підготовленості гімнасток за критеріями: постава, виворотність і натягнутість ніг, стійкість, точність рухів руками і ногами, закінченість, легкість і злитість рухів, музикальність, танцювальність, ілюстративна й емоційна виразність. Апробація запропонованої методики оцінки здійснювалася групою з п’яти фахівців зі спорту (хореографів і тренерів з аеробної гімнастики). Узгодженість результатів оцінювання підтвердилася коефіцієнтом конкордації $(>0,7)$. Визначено рівні хореографічної підготовленості на різних етапах багаторічної спортивної підготовки шляхом розрахунку індексу сформованості окремих критеріїв. Виявлено, що груповий індекс сформованості $\left(I_{2 p}\right)$ хореографічної підготовленості на етапі початкової підготовки відповідає низькому рівню $\left(I_{n n}=1,2\right)$; на етапах попередньої та спеціалізованої базової підготовки хореографічна підготовленість відповідає достатньому рівню $\left(I_{n n}=1,5 ; I_{c n}=1,6\right)$. На всіх етапах був відсутній оптимальний рівень хореографічної підготовленості. Це дає підстави для подальшого аналізу окремих показників, що лімітують рівень хореографічної підготовленості. Об'єктивна оцінка хореографічної підготовленості гімнасток дозволяє більш якісно оцінити хореографічні елементи й уникнути суб’єктивності при визначенні рівня хореографічної підготовленості.

Ключові слова: хореографічна підготовка, оцінка, критерії, рівні хореографічної підготовленості, спортсмени, хореографія програми.

Reviewed by Doctor of Pedagogy, prof. P. Dzhurynskyi 